\title{
Family, tutors and school: inseparable link of the upper middle-level student
}

\section{Familia, tutores y escuela: vínculo inseparable del estudiante de nivel medio superior}

\author{
SESENTO, Leticia`\& LUCIO, Rodolfo“" \\ 'Colegio Primitivo y Nacional de San Nicolás de Hidalgo, Mexico. \\ "Universidad Michoacana de San Nicolás de Hidalgo, Faculty of Veterinary Medicine and Zootechnics, Mexico.
}

ID $1^{\text {st }}$ Author: Leticia, Sesento / ORC ID: 0000-0002-6456-058X, Researcher ID Thomson: S-6997-2018, CVU CONACYT ID: 449302

ID $1^{\text {st }}$ Co-author: Rodolfo, Lucio / ORC ID: 0000-0002-0535-3652, Researcher ID Thomson: X-2391-2018, CVU CONACYT ID: 947303

DOI: $10.35429 / J S E M .2021 .22 .8 .1 .8$

Received January 10, 2021; Accepted June 30, 2021

\begin{abstract}
The beginning of a university career is an opportunity that is given to young people when accessing higher education in Mexico, for the student it is hard work and at times it is saturated with difficulties, which manage to resist with motivation, and study habits that help students to finish the university career. The overall objective of this research is to analyze and promote habits to develop the Action Plan Tutorial of the next school year to promote activities that are in line with the interests of students. It is a crosssectional descriptive investigation through surveys, since variables are not manipulated by naturally targeting phenomena or facts. To carry out this research, a simple sampling was carried out with second and fourth semester students of the Engineering degree in Material Innovation of the UMSNH (Universidad Michoacana de San Nicolás de Hidalgo). Description of the instrument. Study habits test, admits to appreciating and detailing study habits; which can be managed in groups and/or individual, in an average time of 15 minutes, consists of 20 items. With regard to the questioning if, do you study periodically and not just before the exam? $47 \%$ of students refer to only studying from time to time, while $32 \%$ study almost always. Environmental condition factors, study planning, material utilization, content assimilation, and sincerity of study habit scales generally show a low-to-normal moderate utilization level trend. Study habits in their different factors require improving the degree of use.
\end{abstract}

Study habits, Students, Higher level, Engineering

\section{Resumen}

Es importante vincular a los padres de familia con la escuela en estudiantes de nivel medio superior; la familia tiene un papel importante en el desarrollo de los sujetos, sobre todo ahora que, debido a la pandemia del Covid-19, pasan gran parte de su tiempo en casa. En este contexto, los medios de comunicación masiva han tenido gran influencia, situación que propicia que el estudiante se encuentre saturado de gran número de información, ocasionando que ellos imiten formas diversas de conducta de otros países y de otras culturas ajenas a la nuestra. El objetivo conocer el punto de vista de los padres de familia sobre las charlas que se impartieron. De la misma forma se conocieron inquietudes sobre charlas de interés para padres de familias sobre problemáticas que pueden impedir un óptimo desarrollo a los jóvenes. Habrá que reconocer la trascendencia de la participación de los padres de familia a través de programa de acción tutorial, si se cuenta con la alianza de padres de familia será mejor.

Padres de familia, Estudiante, Nivel medio superior, Acción tutorial

Citation: SESENTO, Leticia \& LUCIO, Rodolfo. Family, tutors and school: inseparable link of the upper middle-level student. Journal of Systems and Educational Management. 2021. 8-22:1-8.

*Correspondence to Author (Email: leticiasesentogarcia@yahoo.com.mx)

$†$ Researcher contributing as first Author. 


\section{Introduction}

The present work analyzes the importance of the participation of parents in the education of upper secondary level students. In adolescence, the intervention of parents from home to strengthen school activities and in educational institutions is transcendental, training as agents of change in them. In the tutorial action program at the upper secondary level, the close relationship between parents, tutors and teachers is substantial. Parents are a key segment in the advancement of their children's after-school jobs. In this stage of training, parents are rarely taken into account to support their children's school responsibilities. This is achieved through the linked work of parents, teachers and students in relation to a common project to develop capacities, habits and attitudes (intellectual, cognitive and social). For this reason, it is significant that from an early age the child is conceived accepted, esteemed by their relatives, teachers and classmates. It is frequent to make the mistake of seeing the student as an isolated fraction of the environment in which he operates, the fundamental role that parents play in this stage of formation for their children is frequently neglected, where they demand precise communication and support in the progress of their extracurricular and school activities.

\section{Development}

The factors that intervene in the school performance of the upper secondary student are, among others, social environment, family environment, the cultural level of their parents and the relationship between family and school. It is important to point out that the aforementioned factors intervene in the problem of school dropout and failure. The National Institute for the Evaluation of Education (INEE, 2003) ensures that to improve the quality of education, an effective interaction between parents and teachers is essential, which implies having basic equipment at home, access to the media, optimal schooling of parents, good expectations that their children obtain higher education, that parents have the habit of reading, participation of parents in schoolwork and in parent meetings at school. It is important to highlight the need to guide parents in their educational task with their children, especially in some topics such as: orientation to health, education and development of adolescents. (Franco 1994).

\section{Theoretical framework}

For Alvira (1998), the family has undergone economic, cultural and social changes, video games, the internet, social networks and television have become a means of entertainment and teaching. However, and this is important, the home must be constituted as the space that gives security to the adolescent, since it is a period of both physical and psychological transformations, which makes young people a high-risk group. Youth behaviors that have been recognized as a risk component are: especially early sexual relations, without protection and with multiple partners; heavy use of alcohol and various drugs, including tobacco; the driving of vehicles at an early age and the little use of protection (seat belt, helmet in the case of motorcycles), while intoxicated or being a passenger of a drunk driver, prone to physical fights, essentially carrying bladed weapons or of fire.

The adolescent has the need to face very different problems. The family is the natural biological group of the human being, it is a social compound that encompasses the generality of the segments in a society. In the family it is where they carry out the socialization functions, in its perimeter the individual obtains his identity and the intergenerational individual position, symbolizes the forms of progress and well-being of adolescents. Alvy (1994) maintains that the family has five functions and responsibilities: the provision of basic resources for subsistence, home care, protection of young people, guidance, promotion of physical and psychological progress of these, protection and support of youth origin before the community. Work in the family is a precise component in the preservation of health or in the appearance of disease among its members (Jiménez, 2001).

In 1978 the World Health Organization brought together a commission of experts to define family health and propose indicators for the analysis of the state of health in the family and family groups in the world, depending on the time and the result, dysfunctional families emerge, whose members not only experience a reversal of values, but also have difficulty assuming self-criticism. These vulnerable family structures have serious effects in the early years, but are more evident in adolescence, since it is the segment of life where an individual's personality must surely be formed. 
According to Gonzalvo (1993), the family has always been recognized as one of the most relevant variables in the origin and maintenance of risk behaviors. The association between family functioning and these behaviors on the part of children has been the subject of numerous investigations. Most of these studies highlight the need to involve the family in the prevention and treatment of the onset of substance use and even drug addiction (Iraurgi, 2004). For this reason, it will be important to know the types of family.

\section{Types of family}

The different types of family are not only those that are traditionally known but also exist: the nuclear family (father, mother and children), extended or consanguineous family (it is more than a nuclear unit with a mixture of two generations parents, children, grandparents, uncles, nephews, cousins), the single parent family (only one parent and their children), the single mother family (mother who only takes care of her child or children), the family of separated parents (when both parents they are separated but fulfill their role). Therefore, it is not only an important process that parents must carry out together with their children, it is also an obligation of each guardian to collaborate in the education of her children. It is essential that parents accompany their children in physical, motor, cognitive, school, social and intellectual development. (Oliva; 2003).

Children are initially formed in the family, hence the importance of establishing healthy and stimulating relationships in an environment that allows them to understand and develop their social, cognitive and adaptive skills to the environment. The first years of life are decisive in the formation of an individual's personality. What is lived at home, what parents transmit through not only spoken but affective language. Outstanding theorists of child development, such as Freud, Maslow and Erikson, assure that it is in the stage of two to five years when children shape their emotions and personality, as well as the processing of fears, to lose love, security, control of anguish and anxiety, with which they will face life.
The family has the responsibility of forming principles, values, and security attitudes in the first years of the child's life, which cannot be delegated to other socializing agents. Salazar (2013) indicates that the family, the social nucleus where the individual is formed, is the most complex of institutions, since today this social group continues to exercise (positively or negatively) educational, religious, protective, emotional functions, recreational and productive that put the student in a vulnerable situation.

\section{Family factors}

School performance also depends on the context in which the family and the student develop, because it is important the perception that young people have about the positive or negative evaluation of their family towards them, their knowledge of the support that the family gives them, the Parents' perception of homework, their expectations, communication with students, and concern for them. Oliva and Palacios (2003) indicate the importance of studying the similarities and differences between the family and school environment, they point out the consequences of the different contexts on the educational process, the development of the child and the adolescent. The family context of the student establishes the economic, social and cultural aspects that reach to circumscribe or benefit their personal and educational progress. The attitude that parents share with their children towards education, culture, teachers and school exercises great attribution in their learning process (Oliva \& Palacios, 2003).

UNESCO (2004) mentions important reasons for the participation of parents in the education of their children, firstly, because the bond that exists between parents and children improves learning, secondly, the father and mother are the first educators of their children and this shows a positive impact of quality early education on the development and learning of young people. Currently the family faces great economic, cultural and social changes, urbanization is growing day by day, women have the opportunity of education, women have joined the workforce, for this reason the role of caring, feeding and educating children is no longer a role exclusively of the mother. 
For Rojas (2007), nowadays a problem that is becoming alarmingly general in Mexican society is family disintegration, this phenomenon has the effect of the multiplicity of single-parent families, children cared for by people other than their parents and on minor occasions they come to an empty home. At times it seems that the adolescent upon entering the upper secondary level in public educational institutions, we observe it as an isolated piece of the process, where only the teacher and the students are the essential factors in its use.

Solares (1998, pp. 100-103) mentions that "in the social trajectory of individuals, the family plays a leading role, where together with the school it is responsible for the cultural transition; its efficiency depends on the degree to which the family itself participates in this culture. The family supports the evolution of young people, controlling them and helping them in the process of schooling and progressive introduction in different social environments".

In the development of the tutoring, the tutor must interlace the efforts of parents and students. That is, to be at the service of reconciliation, and the establishment of alliances with parents, involved in the educational process, without the directors, teachers and tutors, these steps will not be possible. In the same way, it will be the key piece that must foster alliances with parents at all times, since the responsibility of educating is not only; It falls on the school and the teachers, but on the family. Finally, those who educate are the parents: our task is to instruct, but the protagonists of education are the parents. Since we remember that the family is the cell of society and it is in it where our young people acquire most of the learning that will be useful for their lives. (Solares 1998).

The practice of mentoring can be exercised at different times and for other purposes. It must include a set of skills called generic, which must be covered by all teachers in their role as tutor. To contribute to the clarification of this practice, immediately establishes a characterization of the profile of the tutor teacher, as a generator of processes of accompaniment of the students during the different moments and situations, faced throughout their professional training, since as we all know it is not an easy task to do.
Academic tutorials have been instituted as one of the main instruments to strengthen the teaching-learning process, the new educational models conceive that it is convenient to evolve the teacher-student relationship to enhance the skills of the latter.

However, in the tutoring action it is essential to interweave efforts with parents, tutors and teachers, promote talks with parents; since dialogue and communication between parents and children are essential. We must not forget that in adolescence, students face changes that cause demotivation in their schoolwork, and consider themselves more fascinated by what goes on around their classroom, (internet, friends, girlfriend and sometimes drugs), however, Young people are owed to offer autonomy, but this we have not educated them to practice it with commitment and that is where we are failing educational institutions and the family. Since we are not used to setting limits and above all we have not educated our young people that freedom is a right that is earned with commitment. (Contreras (2000).

The tutoring work has repeatedly discovered that in the academic stumbling blocks of our young people there is, to a greater or lesser extent, co-responsibility of the parents. This observation is reinforced by the work of Dr. Di Segni, since our student population comes from social strata with limited resources (Di Segni, 2006). Likewise, one of the attributions that teachers of adolescents from families of low socioeconomic and cultural level make of poor performance and failure in school, are located exclusively at the family and adolescent level.

Unfortunately, few parents come to school to find out first-hand about the performance of young people. And although the resources available to the school could be improved, the fact is that parents do not take advantage of the support and guidance that the school personnel provide to address the academic problems of students. (Esteinou, 2010).

Although this seems obvious, one of the most frequent problems in tutoring work is that it loses sight of the limits of the function and, in some cases, it is about addressing problems for which most of the teachers are not trained and nor does it correspond to us. 
Another condition is that the material should contain essential, objective and clear information, avoiding the temptation to saturate the father of the family and, in this way, make it difficult for him to sustain her direct and determined participation.

Objective: To know the opinion of parents about the talks held during the 20202021 semester at the Colegio Primitivo y Nacional de San Nicolás de Hidalgo. This research aims to support the development of tutorial action programs and educational research.

\section{Methodology}

A quantitative investigation was carried out. Through a simple random sampling in the last meeting of parents, in the same way, a questionnaire of 15 questions on a Likert scale was applied under the following reasoning: Excellent, very good, regular and bad through Google drive where the more significant questions were:

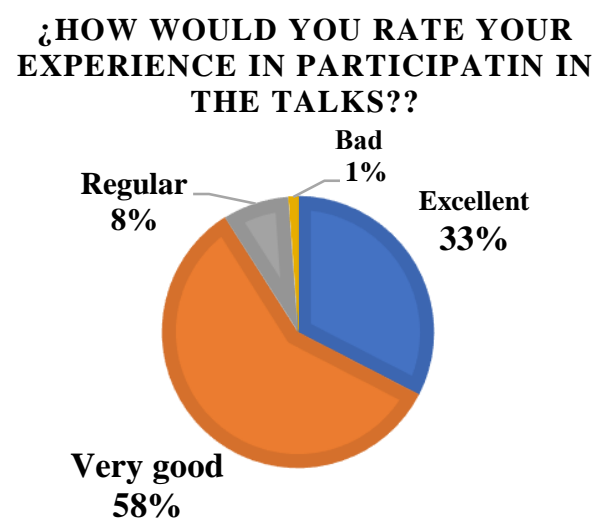

Graphic 1

$5.62 \%$ have primary, secondary $19.10 \%$, Baccalaureate $35.96 \%$, Technical career $5.62 \%$, Bachelor's degree $21.35 \%$, Postgraduate $10.11 \%$ and finally another $2.25 \%$

WAS THE PURPOSE OF THE TALKS CONGRUENT WITH THE CONTENT?

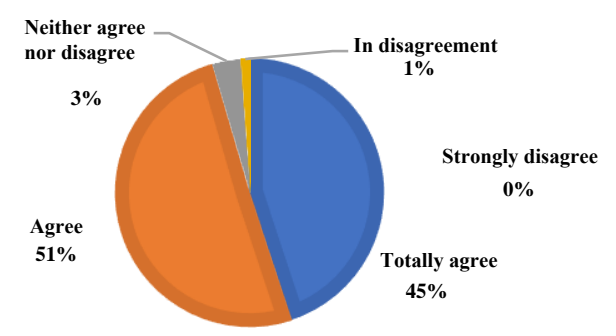

Graphic 2
In relation to the sex of the respondents, they are women $84.27 \%$ and men $15.73 \%$.

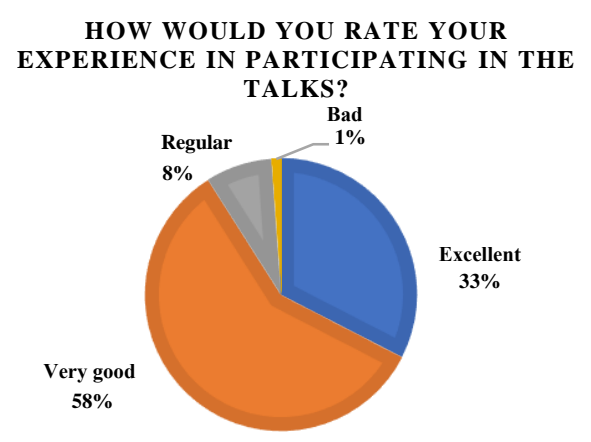

Graphic 3

Regarding the questioning of How would you rate your experience in participating in the talks? Excellent $32.58 \%$, very good $58.43 \%$, Fair $7.87 \%$, Poor $1.12 \%$.

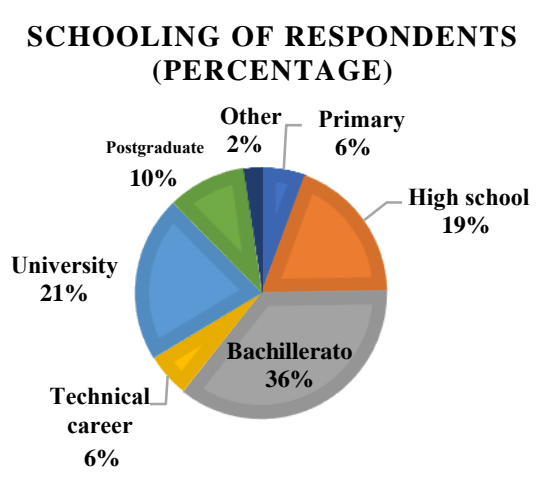

Graphic 4

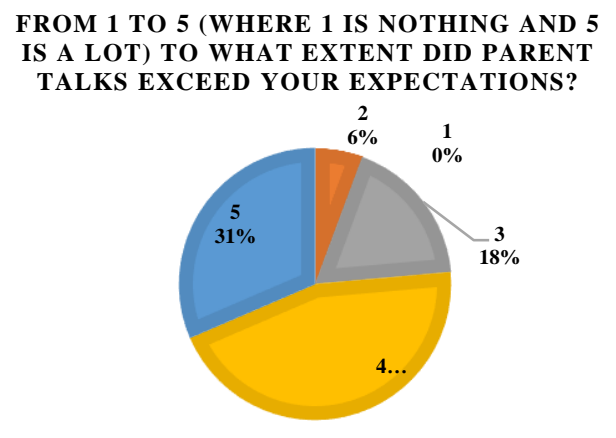

Graphic 5

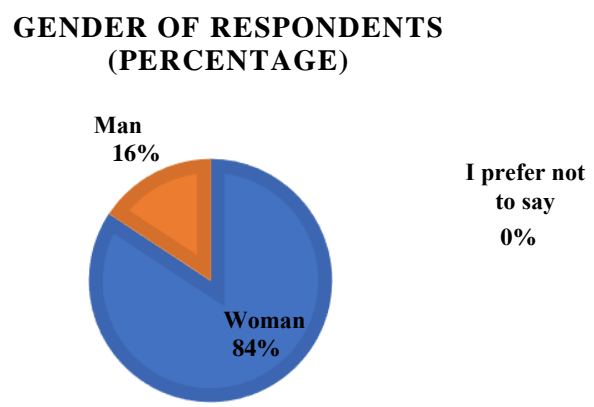

Graphic 6

SESENTO, Leticia \& LUCIO, Rodolfo. Family, tutors and school: inseparable link of the upper middle-level student. Journal of Systems and Educational Management. 2021 


\begin{tabular}{|l|r|r|}
\hline $\begin{array}{l}\text { Did the psychologist who gave } \\
\text { the talk arouse your interest? }\end{array}$ & \multicolumn{2}{|c|}{$\mathbf{N}^{\circ}$ Percentage } \\
\hline Too & 18 & $20.22 \%$ \\
\hline A lot of & 51 & $57.30 \%$ \\
\hline On average & 18 & $20.22 \%$ \\
\hline Little & 2 & $2.25 \%$ \\
\hline Nothing & 0 & $0.00 \%$ \\
\hline Totals & $\mathbf{8 9}$ & $\mathbf{1 0 0 . 0 0 \%}$ \\
\hline
\end{tabular}

Table 1

\section{What topics would you like to see covered in parenting talks next semester?}

Health issues in young people such as mental, emotional, physical health and nutrition.

Family coexistence.

About bullying, respect.

About abortion.

On identifying a drug addict.

Sexuality and drug addiction.

Social networks: risks and benefits

\section{Results}

Definitively, it is essential to continuously provide the student with words that motivate him to continue with his university education. Positive aspects to continue with their studies, constantly emphasizing their achievements and also support in relation to their setbacks. Within the tutorial action there are components that are key aspects, for the success of this, together with an appropriate training of the tutors (initial) the following actions:

It is important to know the problems that the tutors face, since if this is not available, it will be difficult to draw up a tutorial action plan. Coupled with the support of parents.

It was observed that the collaboration and responsibility of the parents are essential for the progress of the tutorial action activities.

Creating alliances with parents facilitated trust with students and tutors.
To the extent that there was trust, patience and respect for the time of the process in the solution on the part of each of the actors involved in the process, better results were achieved.

It is substantial to train parents among other urgent topics on Study Habits and Techniques, and substantial factors for the study would be sensible if they were to be represented in their home, these points are: the physical space in which the task is carried out, the distribution of time of study, the way in which it is studied, the elaboration of works and the way of answering an exam, the production of the task as part of a practice with a specific schedule, choosing an explicit place to carry out the work that has the convenient physical peculiarities that it is adequately lit, that they have the ability to work in a timely manner, have the materials used continuously at hand.

The exercise of tutoring must fall on a teacher who is assumed as a guide of the training process and who is permanently linked to the academic activities of the students under his tutelage, it is necessary to point out certain features that distinguish them from a teacher dedicated preferably to their activity regular in the classroom. The tutor guides, advises and accompanies the student during his teaching and learning process, from the perspective of leading him towards his comprehensive training, which means stimulating in him the ability to take responsibility for his learning and training, so that he can face the challenges that come your way.

\section{Proposals}

1. The importance of the collaboration of parents in academic processes is highlighted, so that teachers, principals and educational authorities support each other in the development of school tasks. Since there will be a decrease in the failure rates, educational lag and possible school dropout.

2. Corresponding to the fact that the National Educational System manages to learn their appropriate practices, retaking practices that have achieved success in different types of service in schools where they manage to favor the optimization of school management and processes. 
3. Promote, by the educational authorities, permanent training programs for tutors.

4. Encourage the tutee the need and desire to solve problems on their own part.

5. Promote the responsibility and participation of parents and guardians.

6. Promote talks with parents, in which they are able to guide them on how to carry out their role in support of the adolescent and not wait for a poor student result to summon the parents, if with an appropriate orientation they can be excellent guides for your children at this stage of their life.

7. Encourage the school for parents where workshops are held that allow them to solve their doubts about their role as parents and the dialogue between their children.

\section{Conclusions}

A guide for parents was developed to serve as an accompaniment during the educational process of their children, so that it involves assertive and timely participation, which was delivered in printed form and with the intention of providing information at least once a semester by this means. , supplemented orally in parent meetings, at the beginning of each course, inviting them to come to the campus when they deem it necessary.

\section{References}

Alvira, Domínguez, Rafael. (1998). El lugar al que se vuelve. Reflexiones sobre la familia. EUNSA, Pamplona. 107 pp.

Alvy, K.T. (1994). Parent training today: A social necessity. Studio City, CA: Center for the Improvement of Child Caring. Berenzon, S., González F., C. y Medina M., M.E. (2000). Asociación entre trastornos depresivos y fóbicos con ideación e intento suicida en mujeres de comunidades urbanas pobres. Revista Mexicana de Psicología, 17(1), 55-63.

ANUIES (2000). Programas Institucionales de Tutoría. Una propuesta de la ANUIES para su organización y funcionamiento en las Instituciones de Educación Superior.
Bricklin, Barry; Bricklin, Patricia, Padres liberales, hijos liberados, Traducción de Angulo, P., Pax, México, 1982.

Castellán, Ivonne. (1995). La familia. Traducción Martínez, H., Fondo de Cultura Económica, México.

Contreras, Luzón, José María. (2000). Pequeños secretos de la vida en común. Planeta, Barcelona 2000, 200 pp.

Di Segni Obiols, Silvia (2006). Adultos en crisis. Jóvenes a la deriva. Ediciones Novedades Educativas de México.

Esteinou, R. (2004). El surgimiento de la familia nuclear en México. México: CIESAS

Esteinou, R. (2010). Las relaciones de pareja en el México moderno. México: Casa del tiempo.

Franco, Gloria Elena. (1994). La comunicación en la familia. Editorial Palabra, Madrid. $4^{\mathrm{a}}$ Edición. 272 pp.

García, C; F y Trejo G.M.R (2007). Tutoría una estrategia educativa que potencia la formación de profesores. México: Editorial Limosa.

González F., C. y Jiménez T., A. (2003). Veinticinco años de investigación sobre suicidio en la Dirección de Investigaciones Epidemiológicas y Psicosociales del Instituto Nacional de Psiquiatría "Ramón de la Fuente". Salud Mental. 35-51.

Gonzalbo, P. (1993). Historia de la Familia. México. Universidad Autónoma Metropolitana.

Hellinger, B. (2005) El centro se distingue por su levedad. Editorial Heder España. 2005 Revista mexicana de pedagogía director Humberto Jerez Año XV No.83 mayor.

INEGI (2013a). Estadísticas a propósito del 14 de febrero, Matrimonio y divorcio en México. Accessed June 23, 2014. Available at: http://www.inegi.org.mx/inegi/contenidos/espa nol/prensa/Conteni dos/estadisticas/2013/matrimonios0.pdf

Instituto Nacional de Estadística, Geografía e Informática (2001). Conteo 2000 de Población y Vivienda. Hermosillo, Son. (México): Autor. 
Instituto Nacional de Estadística, Geografía e Informática (2003). Estadísticas de intentos de suicidio y suicidios (Serie de Estadísticas Continuas, Demográficas y Sociales). México: Autor.

Iraurgi, Ioseba Castillo, Mireia Sanz Vázquez, Ana Martínez Pampliega (2004) Funcionamiento familiar y severidad de los problemas asociados a la adicción a drogas en personas que solicitan tratamiento. Adicciones, Vol.16 núm. 3, págs. 185-195.

Oliva, A. y Palacios, J. (2003). Familia y escuela: padres y profesores. En M. J. Rodrigo y J. Palacios (Coordinadores). Familia y desarrollo humano (pp. 333-350). Madrid: Alianza Editorial.

Rojas, (2007). Enrique. Remedios para el desamor. Cómo afrontar las crisis de la pareja. Temas de Hoy, Madrid. 238 pp.

Salazar, I. (2013). Educación Intercultural para la Paz y la Convivencia Escolar en el Estado de México. Catedra UNESCO, Antioquia, Colombia.

Solares, T. (1998). La participación psicopedagógica de padres de familia para elevar el rendimiento escolar de niños de sexto grado de primaria. UNAM, México D.F.

Valdés C., A. A., Martín P., M. \& Sánchez E., P.A. (2009). Participación de los padres de alumnos de educación primaria en las actividades académicas de sus hijos. REDIE. Revista Electrónica de Investigación Educativa. 11 (1). Pp. 1-17. Recovered from: http://www.redalyc.org/pdf/155/15511137012.p df.

UNESCO (2004). Participación de las familias en la educación infantil latinoamericana. Santiago: Editorial Trineo. Recovered from: http://unesdoc.unesco.org/images/0013/001390/ 139030s.pdf. 